\title{
CORRESPONDENCE
}

\author{
Correspondents are asked to be brief \\ Treatment of Early Breast Cancer \\ W. P. Greening, F.R.C.S.; G. Y. \\ Feggetter, F.R.C.S. \\ Coccid:an-like Nature of Toxoplasma gondii \\ D. G. Fleck, M.D., and others............111 \\ Contaminated Drip Fluid \\ I. T. Stuttaford, M.R.C.S., M.P...........112 \\ Herpes Simplex and Temporal Lobe \\ Ep;lepsy \\ Constance A. C. Ross, M.D..............112 \\ Aetiology of Varicosity \\ A. A. R. Gossage, M.R.C.s. \\ Treating Incontinence Electrically \\ C. D. Collins, F.R.C.S., and Eileen \\ Montgomery; J. P. Williams, F.R.C.S., \\ and S. L. R. Stanton, F.R.C.S...........112 \\ Benign Breast Swelling \\ D. H. Patey, F.R.C.S. . \\ Serological Reactions in Erythema Multiforme
}

N. R. Grist, F.R.C.P.ED., F.R.C.PATH.....113
Skin Trauma and Corticosteroids

Joan Sneddon, Cortico

Child Abuse Syndrome

W. H. Parry, M.D., and Margaret W.

Seymour, D.P.H.; S. M. Smith, D.P.M...113

Rickets in Glasgow Pakistanis

J. M. Round, B.SC.

Febrile Convulsions in Early Childhood

J. Wilson, F.R.C.P.....................114

Carcinoma of Tongue

R. A. Cawson, M.D.

Fenfluramine and Pigmented Naevi

D. W. Bartlett, M.R.C.S.

Quantitation of Transplacental

Pharmaceutical Literature

A. G. Shaw, F.P.S

Age and Anorectal Dilatation

Katharine M. Fussell, F.R.C.S.

Slimming and Efficiency

P. T. Monard, M.SC., M.B............115
Unwanted Pregnancies

Kathleen M. Huntington, M.B..........115

Infection in Rheumatoid Disease

H. C. Burry, M.R.C.P..........

C. M. Fletcher, F.R.C.P.................116

Plantar Warts

D. C. Shields, M.B.; W. G. R. M. Laurie,

M.B.; S. S. Sanders, M.B................116

Stress and the Schizophrenias

W. L. Neustatter, F.R.C.P..............116

Change of Address

M. R. Draper, B.A.

New Consultant Contract

A. I. Mackenzie, F.F.A. R.C.S...........117

Rate for the Specialty

J. A. C. Neely, F.R.C.s...............117

Hands off Postgraduate Centres

G. C. Davy, M.A., F.H.A.....

Primary and Community Care

P. E. Brown, M.R.C.P.

\section{Treatment of Early Breast Cancer}

SIR,-It would be a pity if criticism of technical detail were allowed to detract from the enormous contribution which the Guy's trial (20 May, p. 423) has made to the current discussion about the management of women with operable breast cancer.

It is the first prospective trial which has confirmed what others have concluaied from clinical experience-namely, that the breas can be conserved safely when the axillary lymph nodes are not involved and, probably, when the tumour is small and not multifocal

In the management of breast cancer it is essential to know if the axillary lymph nodes are invaded. One conclusion that might be drawn is that at the time of the tylectomy the nodes in the lower axilla below pectoralis minor (level 1) should be removed. If on frozen section examination they are invaded, the axillary dissection should be completed in conjunction with a total mastectomy. If the nodes are histologically clear, further treatment could be limited to irradiation of the breast and perhaps the parasternal nodes.

This approach would retain the uninvolved nodes in levels II and III of the axilla. The W.H.O. Breast Group is trying to include this kind of approach into a future trial.-I am, etc.,

W. P. GreENING

The Breast Unit

Royal Marsden Hospital,
London S.W.3

SIR,-I am very interested in the "Report after Ten Years of a Clinical Trial" (20 May, p. 423) and agree that results in stage 2 patients treated by local excision and radiotherapy were so inferior to radical excision and radiotherapy that for them this procedure should be abandoned, but I wonder whether it is not a mistake to continue with it in stage 1 patients.
Though the information is incomplete (actual yearly figures, cause of death, time of appearance of metastases, etc.) it is possible to reach such a conclusion by studying the graphs and the statistics supplied. There were 220 stage 1 patients admitted to the trial in ten years, an average intake of 22 per year, half being treated by local excision with radiotherapy and half by radical excision and radiotherapy, but only 110 of these have been in it for more than five years, the remainder being too few in each additional year for analysis.

By the end of five years after operation $20 \%$ were dead (Fig. 2), leaving 88 survivors, half having had one form of treatment and half the other. Distant dissemination was equal in both groups, but local recurrence was much higher in those treated by local excision and radiotherapy. Thus the incidence of local recurrence was (Fig 3): (a) Local excision and radiotherapy $20 \%$ of 44 patients =9; (b) Radical excision and radiotherapy $4 \%$ of 44 patients $=2$.

Within 10 years of the beginning of the experiment local cancer recurrence rate was (Tables III and IV): (a) Local excision and radiotherapy -15 patients; (b) Radical ex cision and radiotherapy -4 patients.

Twelve of the 15 patients with local recurrence after local excision and radiotherapy were treated (Table $\mathrm{V}$ ) and of these, six developed distant metastases and six were reported as free from cancer, no postoperative period being given, but in my experience of a carefully studied personal series of 150 patients with carcinoma of the breast operated on more than 10 years previously (some followed for 25 years) not a single patient who developed local recurrence was found to be free from cancer 10 years after it appeared-in spite of all methods of treatment.

Looked at in this way I suggest that the trial in stage 1 patients be terminated as well as in stage 2 , but of course the continued progress of the survivors should be noted and reported.-I am, etc.,

Jesmond,
Newcastle upon Tyne 2

GeORge Y. FegGetTER

\section{Coccidian-like Nature of Toxoplasma gondii}

SIR,-Dr. W. M. Hutchison and others (17 January 1970 , p. 142) showed the coccidianlike nature of Toxoplasma gondii and the sexual part of the cycle in the domestic cat. Although the oocyst has been found in the faeces of domestic cats in surveys in other countries the evidence of transfer from cat to human has always been obscure. Since Dr. Hutchison published his work this laboratory has tried to investigate acquisition of the infection in cases with high or rising toxoplasma dye test titres. Thus the following case may be of interest.

A 40-year-old married woman with two children, a boy aged 5 years and a girl aged 7 years, became ill in October 1971 with lymphadenopathy. The mother's dye test titre rose from $1 / 512$ to $1 / 4,000$, with the toxoplasma IgM titre 1/16. Her boy, however, had a titre of $1 / 8,000$ in January 1972 but no rising titre could be demonstrated. On investigation it was found that the family owned a dog but no cat. Soil samples and samples from a sand pit in the garden were suspended in $2.5 \%$ sodium dichromate. The coarse sediment was discarded and the supernatant concentrated using ether. The resultant concentrate was washed and in jected into mice known to be free from toxoplasma infection. After six weeks the mice injected with washings from the sand developed toxoplasma antibody showing that infective material had come from the sand. At the time of collection the sand samples were moist and frequently used by the cat 